\title{
A dimensão estética (sensível) da Competência Informacional
}

Discente: Eliane Rodrigues Mota Orelo

Orientadora: Dra. Elizete Vieira Vitorino - PGCIN/UFSC

Banca: Dra. Regina Celia Baptista Belluzzo - UNESP

Dra. Elisa Cristina Delfini Correa - FAED/UDESC

Dr. Francisco das Chagas de Souza - PGCIN/UFSC

Dra. Miriam Figueiredo Vieira da Cunha - PGCIN/UFSC

Dr. Márcio Matias - CIN/UFSC

\section{RESUMO}

A Competência Informacional para ser desenvolvida em plenitude deve estar alicerçada em quatro dimensões: Técnica, Estética, Ética e Política. Esta pesquisa aborda a Dimensão Estética da Competência Informacional do Bibliotecário. Ser competente em informação requer habilidades informacionais: identificar as necessidades de informação, conhecer as fontes de informação, elaborar estratégias de busca, avaliar e utilizar a informação de forma ética e responsável, buscando o bem comum. Envolve ainda uma atitude voltada para a educação ao longo da vida. A Dimensão Estética está ancorada nos conceitos de Estética, resgatados da Filosofia. Diz respeito à sensibilidade, a criatividade, a solidariedade e, direcionado ao fazer do Bibliotecário, implica em resgatar os aspectos humanos, culturais e sociais, pouco explorados em virtude de uma formação predominantemente técnica, desde a década de 1930. É uma pesquisa qualitativa e exploratória, já que reflete os aspectos teóricos e conceituais da Estética para a Competência Informacional, e exploratória, pois esta abordagem é relativamente nova no país. Os resultados demonstram que a Estética pode contribuir significativamente para o Desenvolvimento da Competência Informacional do Bibliotecário, despertando um perfil no qual os aspectos humanos e sociais se revelam nas características estéticas como a imaginação, criatividade e sensibilidade, que se reflete em ações que visam o bem estar social, no exercício da cidadania em busca de uma sociedade solidária.

Palavras-chave: Competência Informacional. Dimensões da Competência. Dimensão Estética. Estética. 